\section{Tung teori om hvordan lage robuste systemer}

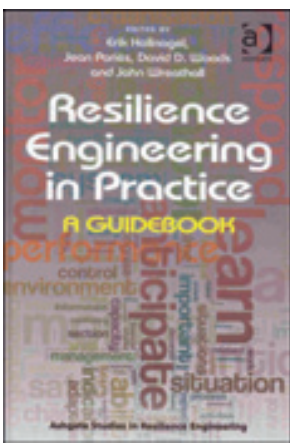

Erik Hollnagel, Jean Pariès,

David D. Woods et al, red.

Resilience engineering in practice

A guidebook. 362 s, tab, ill. Farnham: Ashgate, 2011. Pris GBP 55

ISBN 978-1-4094-1035-5

Risikostyring har vært den tradisjonelle tilnærmingen i sikkerhetsarbeid og er blitt stadig mer populært, også innen medisinen.

I denne sammenhengen har man vanligvis fokusert på de farer og feil som enten har skjedd, eller som man mener truer. Det engelske begrepet «resilience engineering» er imidlertid et nytt fenomen og kan oversettes med evnen til å se svikt og suksess som to sider av samme sak: resultatet av hvordan mennesker og organisasjoner håndterer komplekse og underspesifiserte utfordringer i uforutsigbare omgivelser. Fordi tilgjengelige ressurser alltid er begrensede vil man måtte gjøre en avveining mellom effektivitet og grundighet. Vanligvis går dette forbausende bra, men under gitte forutsetninger varierer forhold og prestasjoner slik at uønskede hendelser oppstår. Robuste systemer har evnen til både å lære, respondere, monitorere og ikke minst forutse hva som skjer, og kan skje. Men hvordan skal man så oppnå dette?

Erik Hollnagel, lege med spesialisering innen flymedisin og professor i industrisikkerhet i Paris og Trondheim, er en «tungvekter» innen den moderne «sikkerhetslitteraturen». Han har dyp innsikt i hvordan systemer både lykkes og feiler, og han er både en glimrende foreleser og forfatter.

I denne boken har han sammen med tre andre kjente kolleger samlet 18 tekster. De 36 forfatterne er både fra USA og Europa, og med ulik bakgrunn presenterer de således ulike perspektiver. Tekstene er naturlig nok dermed også litt varierende i språkføring, og noen av dem kunne med fordel vært strammet litt inn. Det er mange illustrasjoner og tabeller, men ingen foto. I figurene forsøker bidragsyterne å fremstille en del teorier grafisk, og det lykkes delvis, selv om figurtekstene ikke alltid er så forklarende. Jeg fant trykkfeil i figurene, noe jeg strengt tatt ikke hadde forventet. Stikkordregisteret kunne også med fordel vært utvidet, gjerne på bekostning av listene over figurer og tabeller.

Boken er forholdsvis tung teoretisk og egner seg nok fortrinnsvis som lesestoff for de som er over gjennomsnittet interessert. Siden boken er generisk i sin tilnærming til problemstillingen, blir utfordringen å forsøke å overføre de prinsippene som fremføres i tekstene, til praktiske tiltak i en medisinsk sammenheng.

Jeg vil derfor heller anbefale at du leser en av Erik Hollnagels andre bøker. Et godt valg her, og som er noe lettere i sin tilnærming til hvorfor ting som går bra, noen ganger går dårlig, er hans forrige utgivelse på samme forlag (1). Får man tenning da, kan nok denne boken likevel være verdt pengene.

\section{Guttorm Brattebø}

Akuttmedisinsk seksjon

Kirurgisk serviceklinikk

Haukeland universitetssykehus

\section{Litteratur}

1. Hollnagel E. The ETTO principle: Why things that go right, sometimes go wrong. Farnham: Ashgate, 2010

\section{Samfunnsvitenskapelig om HPV-vaksinering}

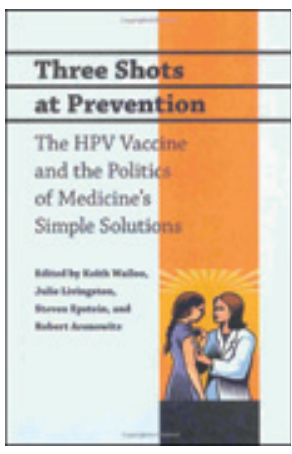

Keith Wailoo, Julie Livingston, Steven Epstein et al, red.

\section{Three shots at prevention}

The HPV vaccine and the politics of medicine's simple solutions. 320 s, ill. Baltimore, MD: The Johns Hopkins University Press, 2010. Pris USD 65

ISBN 978-0-8018-9671-2

Denne essaysamlingen har til sammen 22 forfattere, hvorav 19 har samfunnsvitenskapelig og bare tre har biomedisinsk bakgrunn. Forankring i sosiologi og historie er dominerende blant forfatterne, som alle unntatt tre har tilhørighet til nordamerikanske akademiske institusjoner. Den faglige og geografiske forankringen er forklaringen på at boken nesten utelukkende har et samfunnsvitenskapelig og ikke naturvitenskapelig perspektiv, og i hovedsak behandler nordamerikanske forhold.

Hovedinnholdet er en kritisk analyse av markedsføringen av HPV-vaksinering i USA, som foregår direkte mot publikum, i regi av vaksineprodusentene. Et hovedfunn i analysen er at markedsføringen har konsentrert seg for mye om HPV-vaksinen som beskyttelse mot kreft, i stedet for å rette søkelyset mot at HPVinfeksjonen smitter ved seksuell kontakt. Motivet for denne projiseringen bort fra kjønnssykdom, over på kreftbeskyttelse, har vært å møte motstanden mot vaksinering av prepubertale jenter, basert på at redusert risiko for seksuell smitte medfører økt fare for promiskuitet. I Norge og Europa er direkte markedsføring av legemidler, slik den foregår i USA, forbudt. Dermed har en stor del av innholdet liten relevans for norske forhold.

I kapitlet Public discourses and policymaking. The HPV vaccination from the European perspective gir sosiologen Andrea Stöckl en glimrende fremstilling av ulike kulturers betydning for innholdet i debatten omkring HPV-vaksinering og vaksinering generelt. Hun påviser at motstand mot HPV-vaksinering på moralistisk grunnlag har vært langt mindre fremtredende i Europa enn i USA.

Målgruppen er ikke åpenbar. Den som måtte etterspørre en kritisk vurdering av biologiske innvendinger mot HPV-vaksinering, har intet å hente. Boken kan kanskje være nyttig for helsejournalister, men vil neppe appellere til lesere med en klinisk tilnærming til vaksineproblematikken.

\section{Bjørn Hagen}

Kvinneklinikken

St. Olavs hospital

\section{Lærerike nevrologiske sykehistorier}

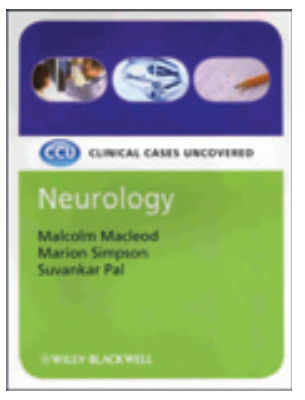

\author{
Malcolm Macleod, Marion Simpson, \\ Suvankar Pal \\ Neurology
}

Clinical cases uncovered. $152 \mathrm{~s}$, tab, ill. Oxford: Wiley-Blackwell, 2011. Pris GBP 22 ISBN 978-1-4051-6220-3

Subjektive plager eller funksjonssvikt som kan skyldes nevrologisk sykdom, er vanlig i befolkningen og hyppig årsak til at lege kontaktes. I dette heftet på drøye 150 sider gjennomgår forfatterne 
sykehistoriene til en rekke pasienter med slike plager og viser innsiktsfullt veien som fører frem til en diagnose gjennom bruk av nevrologisk undersøkelsesmetodikk.

Etter et kortfattet resymé av nervesystemets fysiologi gir forfatterne en del generelle råd om opptak av anamnese, om den kliniske undersøkelsen og om bruk av laboratoriemetoder ved nevrologiske problemstillinger. Hovedinnholdet er en beskrivelse av hvordan man når frem til diagnosen hos 27 pasienter som presenterer seg med forskjellige plager, så som ulike hode- og ansiktssmerter, anfall med svakhet eller kramper, svekket hukommelse, språkforstyrrelser, konfusjon, ustøhet, synsforstyrrelser og parestesier. Både akutte og mer kroniske tilstander drøftes. Mange symptomer og tegn av nevrologisk art som man kan møte i allmennpraksis, akuttmottak eller på nevrologiske poliklinikker, gjennomgås. Forfatterne gir også en forholdsvis kortfattet, men oppdatert oversikt over behandlingsmulighetene for hver enkelt sykdom. Siste del består av spørsmål studenter kan møte ved eksamen i nevrologi. Oppgavene virker svært enkle etter at pasienthistoriene er gjennomgått.

For hver kasuistikk drøfter forfatterne kort i hvilken retning man må tenke ut fra de plager pasienten har søkt lege for. De gir gode råd om viktige anamnestiske opplysninger det er nødvendig å få frem ved samtalen med pasienten, og det understrekes at komparentopplysninger ofte må innhentes. Etter opptak av anamnesen diskuteres de diagnostiske mulighetene som foreligger. En god og målrettet anamnese kan ofte gi grunnlag for å stille rett diagnose og er kanskje den viktigste delen av konsultasjonen hos nevrolog. Nye, detaljerte overveielser gjøres når også funn ved klinisk nevrologisk undersøkelse foreligger. Deretter diskuterer forfatterne hvilke supplerende undersøkelser som ev. bør gjøres for å sikre diagnosen. $\mathrm{Og}$ - i motsetning til hva de fleste nevrologer erfarer i det virkelige liv - greier forfatterne alltid å stille en diagnose enten det foreligger organisk sykdom eller ikke.

Kasuistikkene viser hvor spennende og utfordrende nevrologisk diagnostikk kan være. Boken er full av nyttige drøftinger og praktiske råd basert på solid kunnskap om nervesystemets anatomi, fysiologi og patofysiologi og om det nevrologiske sykdomsspektret. For hver diagnose er det oppgitt referanse(r) til nyere oversiktsartikler. Illustrasjoner og tabeller er oversiktlige, og språket er lettlest engelsk.

Britiske nevrologer går for å være fremragende klinikere, og det gode kliniske skjønn gjennomsyrer teksten. Noe av dette skjønnet kan man nok tilegne seg gjennom lesning, men det viktigste i så måte er øvelse og erfaring gjennom praktisk arbeid under veiledning. Enkelte forskjeller mellom britisk og norsk tradisjon fremkommer; vi er nok raskere (for raske?) til å rekvirere nevroradiologiske undersøkelser - og britene beskriver at vannklar spinalvæske er «gin clear»!

Forfatterne angir at medisinstudenter er den primære målgruppen. Jeg kan anbefale den for alle leger med interesse for nevrologi - som møter pasienter med plager av nevrologisk art, både i allmennpraksis og på sykehus. De praktiske rådene om rasjonell og systematisk tilnærming til nevrologiske problemstillinger vil ikke minst være nyttig lesning for utdanningskandidater ved nevrologiske avdelinger.

\section{Nils Jakob Brautaset}

Nevrologisk avdeling

Sykehuset i Vestfold

Tønsberg

\section{Luftambulansemedisin «down under»}

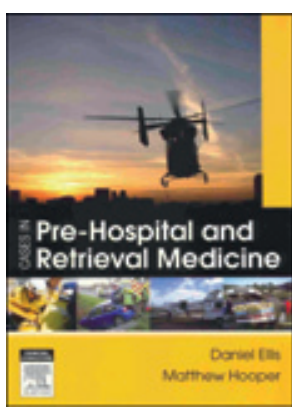

Daniel Ellis, Matthew Hooper

Cases in pre-hospital and retrieval medicine

286 s, ill. Sydney: Churchill Livingstone

Elsevier, 2009. Pris EUR 54

ISBN 978-0-7295-3884-8

Prehospital akuttmedisin er blitt et eget arbeidsfelt for leger i Norge, en utvikling som skjøt fart med etableringen av den nasjonale luftambulanseplanen i 1988. Gode lærebøker på fagfeltet er det få av. Årsaken til det kan være store nasjonale forskjeller i organisering og bemanning av disse tjenestene. Amerikansk litteratur dominerer, men luftambulansetjenesten der er i hovedsak bemannet med «paramedics» og spesialsykepleiere under ledelse av leger som ikke selv er aktive i felten. Derfor er mye av luftambulanselitteraturen, både bøker og tidsskrifter, av begrenset relevans for norske leger.

Forfatterne Daniel Ellis og Matthew Hooper er solide klinikere, med omfattende erfaring i praktisk akuttmedisinsk, prehospitalt arbeid, sivilt og militært, fra England og Australia. Daniel Ellis har nylig forlatt London, og begge er nå basert i Adelaide i Australia, hvor de kombinerer arbeid på sykehus med luftambulansetjeneste. Matthew Hooper er også førsteamanuensis ved James Cook University i Freetown, Queensland.

Forfatternes ståsted er preget av deres inngående kjennskap til mange samarbeidende luftambulansetjenester, ikke minst i Storbritannia. Slektskapet til tjenester som av mange regnes som høyborger for god og reflektert klinisk standard, er tydelig. Ikke minst trekker forfatterne frem mange eksempler og prosedyrer fra London's Air Ambulance (LAA), en av verdens mest velorganiserte og avanserte prehospitale traumeenheter.

Boken gjenspeiler australsk og britisk luftambulansemedisin. Dette gjør den interessant og relevant for norske lesere. Søkelyset er mer likt vårt, på pasient og medisin, ikke så mye på «air medical business», fordi det er tjenester som virker innen rammene av offentlige kontrakter, og i et helsevesen som i hovedsak er drevet av det offentlige.

Gjennom 50 kasuistikker sikter forfatterne mot å belyse den krevende kombinasjonen av sikker, effektiv, klinisk håndtering av akutt og kritisk syke og skadede, med høy kvalitet, under uforutsigelige og utfordrende ytre rammeforhold. Scenariene er gruppert i én prehospital del, én del som omhandler overføringer mellom sykehus, og én del der scenariene belyser systemarbeid og spesielle problemområder. Forfatterne utdyper sentrale prinsipper i effektiv utnytting av alle tilgjengelige ressurser (crew resource management, CRM) og klinisk kvalitetsledelse (clinical governance), med særlig vekt på operativ sikkerhet, menneskelige faktorer, effektiv kommunikasjon og teamarbeid. Situasjonene er hentet fra svært forskjellige omgivelser: storby, distrikt og områder med svært lang transporttid til ressurssenter.

Formatet er standardisert, med scenario, spørsmål og diskusjon, som lett kan relateres til egne erfaringer, og som inviterer til realistisk tilnærming og refleksjon. Drøftingen av scenarier reflekterer den prehospitale akuttmedisinens uforutsigbare natur. Illustrasjonene er glimrende, noe som styrker kasuistikkene og understreker de faglige prinsippene. Det er gode, oppdaterte referanser til juni 2009. Referansene omfatter både medisinsk fagstoff og annen viktig kunnskap, som kunnskap om samarbeidspartnerne og sikkerhet på åsted, som er sterkt vektlagt både i Australia og i LAA.

Appendiksene er nyttige og interessante. Det gjelder prosedyrer, utstyrs- og medikamentoversikter, sjekklister, ordliste og en samling av fasitforslag til problemstillingene som man diskuterer i kasuistikkene. 